\title{
Evaluation of a Colostrum Supplement, With or Without Trypsin Inhibitor, and an Egg Protein Milk Replacer for Dairy Calves*'
}

\author{
H. M. Santoro, ${ }^{1}$ P. S. Erickson, ${ }^{1}$ N. L. Whitehouse, ${ }^{1}$ \\ A. M. McLaughlin, ${ }^{1}$ C. G. Schwab, ${ }^{1}$ and J. D. Quigley, III ${ }^{2}$ \\ ${ }^{1}$ Department of Animal and Nutritional Sciences, \\ Ritzman Laboratory, \\ University of New Hampshire, Durham 03824 \\ ${ }^{2} \mathrm{APC}$, Inc. \\ Ames, IA 50010
}

\begin{abstract}
Forty-eight Holstein bull calves were assigned to a $2 \times$ $2 \times 2$ factorial arrangement in a completely randomized block design. Main effects were colostrum versus a serum-derived colostrum supplement, 0 versus $1 \mathrm{~g}$ of trypsin inhibitor added at the initial 2 feedings, and milk replacer containing 0 or $50 \% \mathrm{CP}$ from whole egg. Calves were bled at $0,6,12,18$, and $24 \mathrm{~h}$ after birth for determination of serum immunoglobulin (Ig). G. Serum IgG concentrations were lower in calves consuming the colostrum supplement compared with calves consuming colostrum. Apparent efficiency of absorption of IgG was similar. Trypsin inhibitor did not affect IgG concentrations or absorption of IgG. Calves were fed either milk replacer for 28 to $35 \mathrm{~d}$ (preweaning phase) and weaned when they consumed $0.7 \mathrm{~kg}$ of starter grain for 2 consecutive days. The postweaning phase was from weaning to d 56. Feeding colostrum supplement resulted in higher fecal scores postweaning (1.90 vs. 1.58$)$ and overall (1.85 vs. 1.65$)$ and fewer days medicated preweaning (5.1 vs. $2.2 \mathrm{~d}$ ) and postweaning (3.9 vs. $1.9 \mathrm{~d}$ ) and overall (9.0 vs. $4.2 \mathrm{~d}$ ). Calves were treated for upper respiratory tract infections and diarrhea. Dry matter intake and weaning age were not affected by treatment. Postweaning (1.69 vs. $1.2 \mathrm{~kg}$ ) and overall (1.22 vs. $1.0 \mathrm{~kg})$, calves that received colostrum and egg milk replacer consumed more dry matter and starter. Postweaning, calves fed colostrum and egg milk replacer had similar or greater body weight and gains compared with calves fed colostrum and milk protein milk replacer.

Preweaning, feed efficiency was greater for calves fed colostrum (0.44 vs. 0.34 ), trypsin inhibitor (0.42 vs.

\footnotetext{
Received: June 16, 2003.

Accepted: October 24, 2003.

Corresponding author: P. S. Erickson; e-mail: peter.erickson@

*This is Scientific Contribution Number 2183 from the New Hamp-

$†$ Support for this project was through APC, Inc., Ames, IA, and
} unh.edu. shire Agricultural Experiment Station. the New Hampshire Agricultural Experiment Station, H-395.
\end{abstract}

$0.36)$, and milk protein milk replacer (0.48 vs. 0.30$)$ compared with calves fed colostrum supplement, no trypsin inhibitor, and egg milk replacer, respectively. Trypsin inhibitor increased feed efficiency postweaning. Calves fed trypsin inhibitor and milk protein milk replacer were more efficient preweaning and overall than calves fed trypsin inhibitor and egg milk replacer. Results indicate that the blood derived colostrum supplement did not provide as much IgG as colostrum (4.55 $\mathrm{g} / \mathrm{L}$ vs. $14.6 \mathrm{~g} / \mathrm{L}$, respectively), that feeding $1.0 \mathrm{~g}$ of trypsin inhibitor did not enhance serum IgG concentrations, and that the egg milk replacer-fed calves fed colostrum performed nearly as well as calves fed colostrum and the milk protein milk replacer.

(Key words: calf, colostrum substitute, trypsin inhibitor, egg milk replacer)

Abbreviation key: ADG = average daily gain, AEA = apparent efficiency of IgG absorption, AMR = all milk protein replacer, $\mathbf{C S}=$ colostrum supplement, $\mathbf{E M R}=$ milk replacer containing spray-dried whole egg, $\mathbf{M C}=$ maternal colostrum, $\mathbf{M R}=$ milk replacer, $\mathbf{T I}=$ trypsin inhibitor.

\section{INTRODUCTION}

Immunoglobulins can be isolated from milk and other animal tissues, such as blood, and recently have been used in colostrum supplements (CS) for calves. However, CS do not provide the necessary energy and vitamins or contain the AA profile of maternal colostrum (MC). Therefore, CS are typically used on the farm in conjunction with $\mathrm{MC}$ as a means of increasing the amount of IgG delivered to the newborn calf. Using Ig from bovine serum as a CS, Quigley et al. (1998b) and Arthington et al. (2000) observed no differences in disease incidence. Whereas Arthington et al. (2000) reported that calves fed CS had increased efficiency of absorption of IgG when compared to calves fed MC, the serum IgG concentration of calves fed MC was higher (12.1 g/L vs. $6.8 \mathrm{~g} / \mathrm{L})$. Quigley et al. (1998b) reported that efficiency of IgG absorption was lower in calves fed CS compared with calves fed MC. 
Trypsin secreted by the small intestine can degrade colostral antibodies, and bovine IgG is susceptible to tryspin degradation (Quigley et al., 1995a). Colostrum from species dependent on passive transfer of immunity, such as the bovine, contains more trypsin inhibitor (TI) than milk. Bovine colostrum contains 100 times the TI of milk (Sandholm and Hokanen-Byzalski, 1979). Trypsin inhibitor is low in $\mathrm{MC}$ of species that do not depend on colostral transmission of Ig (Quigley et al., 1995b; Sandholm and Hokanen-Byzalski, 1979). Colostral TI may help to protect IgG without preventing the digestion of other milk proteins (Quigley et al., 1995b). Adding soybean TI to MC resulted in higher serum concentrations of IgG and IgM in the first $48 \mathrm{~h}$ of life compared with calves fed MC (Quigley et al., 1995b).

Fifty percent of the dairy replacement heifers born in the United States are fed a milk replacer (MR) at some point before weaning (Heinrichs et al., 1995). Contemporary formulations result in growth rates similar to calves fed whole milk with the benefit of lower cost per unit gain (Davis and Drackley, 1998). However, identifying a high-quality and low-cost protein source has been challenging. There has been recent interest in using waste eggs in MR. Cracked or damaged eggs that are not usable for human consumption may be spray dried and used as a MR protein source. However, BW gains of calves fed MR containing spray-dried whole egg (EMR) were less than calves fed all milk protein replacer (AMR) (Scott et al., 1999; Quigley, 2002; Catherman, 2002). In contrast, Kellogg et al. (2000) found no differences in BW gains when EMR was substituted for all milk replacer.

The objectives of this experiment were to determine whether the quality of CS and MC could be enhanced by the addition of $1 \mathrm{~g}$ of soybean TI, and to determine whether an MR containing 50\% of its protein from eggs is an effective substitute for an AMR.

\section{MATERIALS AND METHODS}

\section{Calves, Feeding, and Treatments}

Forty-eight Holstein bull calves (initial BW of 47.1 $\pm 4.7 \mathrm{~kg}$ ) were assigned at birth to one of 8 dietary treatments arranged in a $2 \times 2 \times 2$ factorial arrangement of treatments. Main effects were MC versus CS (Lifeline, APC, Inc., Ames, IA), $0 \mathrm{~g}$ versus $0.5 \mathrm{~g}$ TI added to each feeding of MC or CS, and AMR (0\% egg) versus EMR (50\% CP from egg) (APC, Inc.). Calves were blocked in groups of 8 as calves were born. Randomization of treatment occurred within block. The first 40 calves assigned to the experiment were born at the University of New Hampshire Dairy Teaching and Research Center. The last block of calves was purchased from a local farm. All calves were separated from their dam at birth, navels dipped in tincture of iodine, and placed in individual pens bedded with kiln-dried sawdust (university-born calves) or shavings (local farm). Calves born at the local farm were transported $12 \mathrm{~km}$ to the University of New Hampshire Dairy Teaching and Research Center within $24 \mathrm{~h}$ of birth. This study was approved by the Institutional Animal Care and Use Committee at the University of New Hampshire (IACUC \#990502).

Calves remained in individual pens for the entire experiment (56 d). Twenty-four calves were fed $2 \mathrm{~L}$ of good quality pooled colostrum $(7.3 \% \mathrm{IgG}) \pm \mathrm{TI}$, whereas the other 24 calves were fed the CS $(\operatorname{IgG}=10 \%) \pm \mathrm{TI}$ (Type II-S; crude soluble powder; Sigma Chemical Co., St. Louis, MO) within 90 min of birth. Colostrum was collected from cows immediately after parturition and Ig content was estimated using a colostrometer. Only colostrum that was estimated to be of good quality based on colostrometer reading ( $>50 \mathrm{~g} / \mathrm{L}$ of IgG) was used. Colostrum was pooled from cows in our closed herd, stored in 2-L plastic bottles, and frozen at $-20^{\circ} \mathrm{C}$ until thawed in lukewarm water (approximately $40^{\circ} \mathrm{C}$ ). Colostrum was pooled to reduce variation in IgG concentration. For calves not receiving $\mathrm{MC}$, one packet (454 g) of $\mathrm{CS}$ was suspended in $2 \mathrm{~L}$ of warm $\left(50^{\circ} \mathrm{C}\right)$ water. The TI was added to MC or CS at a rate of 0.5 $\mathrm{g}$ per feeding. Calves received a second feeding of $\mathrm{MC}$ or CS \pm TI $12 \mathrm{~h}$ ( $\pm 10 \mathrm{~min}$ ) after birth. Both the CS and the TI went into solution with gentle stirring. Calves were fed twice daily. At each feeding on $\mathrm{d} 2$ and 3 , and the first feeding on $\mathrm{d} 4$, calves received $2.27 \mathrm{~kg}$ of whole milk. Beginning with the second feeding on d 4, calves were fed either AMR or EMR. The experimental MR were formulated to contain 0 or approximately $50 \%$ of $\mathrm{CP}$ as $15 \%$ spray-dried whole egg, which replaced whey protein concentrate, whey, and fat. Spray-dried whole egg was shipped to a mixing facility where it was dry blended and $22.7 \mathrm{~kg}$ was placed in bags (Animix, Juneau, WI). Milk replacer was prepared by mixing 0.23 $\mathrm{kg}$ of dry MR in $2 \mathrm{~L}$ of warm $\left(60^{\circ} \mathrm{C}\right)$ water. Starter (Calf BT, Blue Seal Feeds, Londonderry, NH) medicated with lasalocid $(110.25 \mathrm{mg} / \mathrm{kg})$ and fresh water was available continuously. The starter consisted of steam-flaked corn, crimped oats, molasses, and pellets. Calves were weaned when they consumed $0.7 \mathrm{~kg}$ of starter for 2 consecutive days or when they reached $35 \mathrm{~d}$ of age. Minimum weaning age was $28 \mathrm{~d}$ regardless of starter intake. Calves concluded the experiment on $d 56$. Preweaning was defined as the period $\leq 28$ to $35 \mathrm{~d}$ of age. Postweaning was defined as the period $\geq 28$ to $35 \mathrm{~d}$ of age.

\section{Feed Samples}

Samples of starter and MR (200 g) were taken from each bag when opened and were composited monthly. 
Feed refusals were collected from each calf daily, weighed, and composited weekly by calf. Subsamples of composited starter, feed refusals, and MR were dried for $6 \mathrm{~h}$ at $60^{\circ} \mathrm{C}$ in a forced-air convection oven (VWR Scientific Products Corporation, Boston, MA), for determination of daily DMI each week. After weighing, dried starter and feed refusal samples were allowed to air equilibrate and then ground to pass through a 1-mm screen (Wiley Mill, Thomas Scientific, Swedesboro, NJ). Dry matter was determined using a vacuum oven at $100^{\circ} \mathrm{C}$ for $6 \mathrm{~h}$. The dried, ground samples of starter and MR (EMR and AMR) were analyzed for CP (AOAC, 1979), and the starter was analyzed for fat (AOAC, 1995). The total fatty acid content of the MR was determined by saponification of MR with $\mathrm{KOH}$ in ethyl alcohol. The fatty acids were liberated from the soaps with $\mathrm{HCl}$, followed by extraction with petroleum ether (AOAC, 1995). The NDF and ADF contents of the starter were determined using the method of Goering and Van Soest (1970).

\section{Blood Samples}

Blood samples were taken from the jugular vein before the first feeding of MC or CS (within $90 \mathrm{~min}$ of birth, referred to as $0 \mathrm{~h}$ hereafter) and at $6,12,18$, and $24 \mathrm{~h}$ after birth. Samples were collected in 7.5-ml Vacutainer tubes containing no additive (Becton Dickinson Vacutainer Systems, Franklin Lakes, NJ). Samples were allowed to clot at room temperature for at least $20 \mathrm{~min}$ and then centrifuged at $3300 \times g$ at $25^{\circ} \mathrm{C}$ for 20 min (International Equipment Co., Needham Heights, MA). Serum was placed in 5 -mL polypropylene tubes and stored at $-20^{\circ} \mathrm{C}$ and later analyzed for IgG by turbidimetric immunoassay (APC, Inc., Ames, IA) as described by Etzel et al. (1997).

\section{Measurements}

Within $24 \mathrm{~h}$ of birth, calves were weighed. Calves were again weighed on Tuesday morning (before 1130 h) for calves born from Sunday to before noon on Wednesday, whereas calves born after noon on Wednesday through Saturday, measurements were made on Thursday mornings. Calves were weighed weekly on these days thereafter. Feces were evaluated and scored by 3 independent scorers each Monday, Wednesday, and Friday over the entire study. With the exception of the senior author, the other scorers were blinded to treatment. A scale of 1 to 4 was used, where $1=$ firm and $4=$ watery and devoid of any solid material. Days medicated were recorded as any day that a calf received a medication. Medication was given to calves that had a fecal score greater than or equal to 3 or that had a rectal temperature greater than $39^{\circ} \mathrm{C}$. Apparent efficiency of IgG absorption (AEA) at $24 \mathrm{~h}$ of age was estimated using the equation: (plasma IgG $[\mathrm{g} / \mathrm{L}] \times \mathrm{BW}[\mathrm{kg}]$ $\times 0.09 /$ IgG intake $) \times 100 \%$ (Quigley et al., 1998a).

\section{Statistical Analysis}

The ANOVA was conducted by using the MIXED procedure of SAS (SAS release 8.1, 2000) for a randomized block design with a $2 \times 2 \times 2$ factorial arrangement of treatments; degrees of freedom were partitioned among block, main effects of $\mathrm{MC}$ versus CS, $0 \mathrm{~g}$ versus $1 \mathrm{~g}$ TI, EMR versus AMR, and covariate. Birth BW was used as a covariate for DMI, average daily gain (ADG), and feed efficiency.

The statistical model was:

$$
\begin{gathered}
\mathrm{Y}_{\mathrm{ijkl}}=\mu+\mathrm{b}_{\mathrm{i}}+\mathrm{I}_{\mathrm{j}}+\mathrm{T}_{\mathrm{k}}+\mathrm{M}_{\mathrm{l}}+\mathrm{Kc}_{\mathrm{ijkl}}+\mathrm{IT}_{\mathrm{jk}} \\
+\mathrm{IM}_{\mathrm{jl}}+\mathrm{TM}_{\mathrm{kl}}+\mathrm{ITM}_{\mathrm{jkl}}+\mathrm{E}_{\mathrm{ijkl}}
\end{gathered}
$$

where

$$
\begin{aligned}
\mathrm{Y}_{\mathrm{ijkl}}= & \text { the dependent variable, } \\
\mu= & \text { the overall mean, } \\
\mathrm{b}_{\mathrm{i}}= & \text { the effect of block } \mathrm{i}(\mathrm{i}=1, \ldots, 6), \\
\mathrm{I}_{\mathrm{j}}= & \text { the effect of Ig source }(\text { colostrums or colos- } \\
& \text { trums supplement, } \mathrm{j}=1,2) \\
\mathrm{T}_{\mathrm{k}}= & \text { the effect of trypsin inhibitor }(\mathrm{k}=1,2), \\
\mathrm{M}_{\mathrm{l}}= & \text { the effect of milk replacer type }(1=1,2), \\
\mathrm{K}= & \text { the regression coefficient of the covariate, } \\
\mathrm{c}_{\mathrm{ijkl}}= & \text { the value of the covariate variables for the } \\
& \text { mth calf, in the ith block, of the jth, Ig } \\
& \text { source, of the kth level of trypsin inhibitor, } \\
& \text { of the lth milk replacer type }(\mathrm{m}=1, \ldots 8), \\
\mathrm{E}_{\mathrm{ijkl}}= & \text { the random error associated with calf } \mathrm{m}, \\
& \text { in block } \mathrm{i}, \text { that received jth Ig source, at } \\
& \text { the kth level of trypsin inhibitor, receiving } \\
& \text { the lth type of milk replacer. IT } \mathrm{T}_{\mathrm{jk}}, \mathrm{IM}_{\mathrm{jl}}, \\
& \text { TM } \mathrm{M}_{\mathrm{kl}}, \text { and } \\
\mathrm{ITM}_{\mathrm{jkl}}= & \text { fixed effects due to the interactions of the } \\
& \text { main effects. }
\end{aligned}
$$

Model-fitting statistics using the Repeated Statement of Mixed Procedure of SAS (Version 8.1) were performed to determine which covariant structure best fit the data. The Schwarz-Babesian criteria were used to determine the model covariance structure (SAS, 2000). It was determined that unstructured covariance best fit the data. Block did not have an effect and was removed from the model to provide additional degrees of freedom. 
Table 1. Serum IgG concentrations and apparent efficiency of absorption of IgG of calves during the first $24 \mathrm{~h}$ after birth fed colostrum or colostrum supplement with or without trypsin inhibitor (TI).

\begin{tabular}{|c|c|c|c|c|c|c|c|c|}
\hline \multirow{3}{*}{$\begin{array}{l}\text { Hours } \\
\text { from birth }\end{array}$} & \multicolumn{4}{|c|}{ Treatment $^{1}$} & \multirow[b]{3}{*}{ SEM } & \multirow{2}{*}{\multicolumn{3}{|c|}{ Contrast $^{2}(P=)$}} \\
\hline & \multicolumn{2}{|c|}{ Colostrum } & \multicolumn{2}{|c|}{$\begin{array}{l}\text { Colostrum } \\
\text { supplement }\end{array}$} & & & & \\
\hline & No TI & $\mathrm{TI}$ & No TI & $\mathrm{TI}$ & & MC vs. CS & No TI vs. $1 \mathrm{~g}$ TI & Interaction \\
\hline & 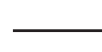 & - $(\mathrm{g} /$ & L) & & & & & \\
\hline 0 & 0.0 & 0.01 & 0.0 & 0.0 & & & & \\
\hline 6 & 5.6 & 5.90 & 2.0 & 2.4 & 0.74 & 0.0001 & $\mathrm{NS}^{3}$ & NS \\
\hline 12 & 9.9 & 9.50 & 3.6 & 3.8 & 0.63 & 0.0001 & NS & NS \\
\hline 18 & 15.5 & 12.10 & 4.3 & 4.7 & 0.85 & 0.0001 & NS & 0.03 \\
\hline 24 & 15.7 & 13.50 & 4.5 & 4.6 & 0.75 & 0.0001 & NS & $\mathrm{NS}$ \\
\hline $\begin{array}{l}\text { Apparent efficiency } \\
\text { of absorption of IgG \% }\end{array}$ & 21.0 & 21.4 & 22.7 & 19.6 & 1.70 & NS & NS & NS \\
\hline
\end{tabular}

\section{RESULTS}

\section{Immunity and Health}

Three calves died during the experiment for reasons unrelated to the experiment. Data from deceased calves were used in the statistical analysis up to the time they died. At $0 \mathrm{~h}$, serum IgG concentrations were $0 \mathrm{mg} / \mathrm{mL}$ except for calves fed $1 \mathrm{~g}$ TI in $\mathrm{MC}(0.01 \mathrm{mg} / \mathrm{mL})$ (Table 1). This was due to a single calf in this group having trace amounts of IgG in the initial blood sample. Calves fed CS had lower IgG concentrations than calves fed $\mathrm{MC}$ over all the sampling times except $0 \mathrm{~h}$. There was no effect of TI on serum IgG concentrations. However, a significant colostrum $\times$ TI interaction for serum IgG was observed at $18 \mathrm{~h}$; a result of TI causing lower IgG concentrations in MC-fed calves (12.1 vs. $15.5 \mathrm{~g} / \mathrm{L}$ ) but higher IgG concentrations in CS-fed calves (4.3 vs. 4.7 $\mathrm{g} / \mathrm{L})$. All calves that received $\mathrm{CS}$ failed to attain passive transfer of IgG by $24 \mathrm{~h}$ ( $<10 \mathrm{~g}$ of IgG/L). Of the 24 calves fed MC, one attained passive transfer of IgG by $6 \mathrm{~h}, 10$ attained passive transfer by $12 \mathrm{~h}, 10$ attained passive transfer by 18 h, 2 attained passive transfer by $24 \mathrm{~h}$, and 1 calf failed to attain passive transfer. Calves fed MC and CS had approximately 20\% AEA of IgG (Table 1).

Thirty-one of the 48 calves had at least one case of diarrhea (fecal score $\geq 3$ ). Fecal scores were higher after weaning and during the entire experiment for calves fed the CS (Table 2). Days medicated during the preweaning ( 5.1 vs. $2.2 \mathrm{~d}$ ) and postweaning (3.9 vs. $1.9 \mathrm{~d}$ ) periods and for the overall (9.0 vs. $4.2 \mathrm{~d}$ ) study were higher $(P<0.05)$ for calves that received CS compared to calves fed MC. Upper respiratory tract infection accounted for $58.3 \%$, diarrhea accounted for $31.3 \%$, diges- tive upsets accounted for $7.4 \%$, and feet and leg problems accounted for $3.1 \%$ of the days medicated.

\section{Feed Intake and Weaning Age}

The chemical composition of the MR and starter is presented in Table 3. Calves consumed all the MC, CS, and MR provided during the preweaning phase. Dry matter intake was not different among treatments in any phase of the experiment (Table 4 ). A significant ( $P$ $<0.05$ ) colostrum $\times$ MR interaction for DMI postweaning was observed, a result of EMR causing a lower DMI in CS fed calves compared with calves fed CS and AMR (1.20 vs. $1.69 \mathrm{~kg}$, respectively), but a higher DMI in MC- and EMR-fed calves compared with calves fed MC and AMR (1.68 vs. $1.50 \mathrm{~kg}$, respectively). Likewise, a similar $(P<0.05)$ colostrum $\times$ MR interaction was observed overall; a result of EMR causing a lower DMI in CS-fed calves compared with calves fed CS and AMR (0.98 vs. $1.19 \mathrm{~kg}$, respectively), but a higher DMI in MC- and EMR-fed calves compared with calves fed MC and AMR (1.22 vs. $1.10 \mathrm{~kg}$, respectively).

Starter intake was similar across all treatments and during all phases (Table 4). As would be expected from the DMI data, a significant $(P<0.05)$ colostrum $\times$ MR interaction for starter intake postweaning was observed; a result of EMR causing a lower starter intake in CS fed calves compared with calves fed CS and AMR (1.16 vs. $1.63 \mathrm{~kg}$, respectively) but a higher starter intake in MC- and EMR-fed calves compared with calves fed MC and AMR (1.61 vs. $1.44 \mathrm{~kg}$, respectively). Likewise, a similar $(P<0.05)$ colostrum $\times$ MR interaction was observed overall; a result of EMR causing a lower starter intake in CS-fed calves compared with calves 
Table 2. Fecal scores and days medicated of calves fed colostrum with (TI) or without trypsin inhibitor (No TI), colostrum supplement with or without trypsin inhibitor, followed by either an all milk protein milk replacer (AMR) or 50\% egg-protein based milk replacer (EMR).

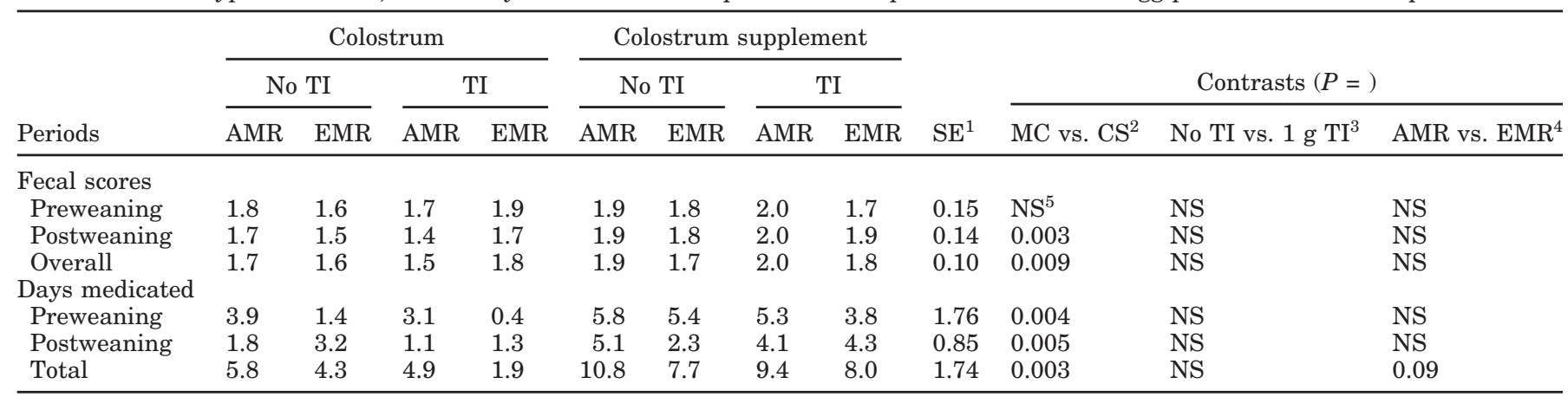

${ }^{1}$ Mean standard error.

${ }^{2}$ Maternal colostrum vs. colostrum supplement.

${ }^{3}$ No trypsin inhibitor vs. $1 \mathrm{~g}$ trypsin inhibitor.

${ }^{4}$ All milk protein milk replacer vs. $50 \%$ egg-protein milk replacer.

${ }^{5}$ Not significant $(P \leq 0.10)$.

fed CS and AMR (0.63 vs. $0.83 \mathrm{~kg}$, respectively) and a higher starter intake in MC- and EMR-fed calves compared with calves fed MC and AMR (0.86 vs. 0.75 $\mathrm{kg}$, respectively). Weaning age (34.25 $\mathrm{d} \pm 1.05 \mathrm{SE})$ did not differ among treatments.

\section{Growth Parameters}

Colostrum feeding had no effect on BW (Table 4). A significant $(P<0.05)$ colostrum $\times$ MR interaction occurred postweaning. Calves fed CS and EMR had lower BW than calves fed CS and AMR (60.4 vs. 69.5 $\mathrm{kg}$, respectively), but higher BW in MC- and EMR-fed calves compared with calves fed MC and AMR (66.8 vs. $65.6 \mathrm{~kg}$, respectively).

Preweaning ADG was decreased $(P=0.003)$ by feeding EMR vs. AMR ( 0.28 vs. $0.40 \mathrm{~kg}$, respectively). Neither TI nor colostrum had any effect on ADG. However, during the preweaning period, a significant $(P<0.05)$ $\mathrm{TI} \times \mathrm{MR}$ interaction was observed. Calves fed TI and EMR had lower ADG than calves fed TI and AMR (0.23 vs. $0.44 \mathrm{~kg} / \mathrm{d}$, respectively). Whereas calves not fed TI had similar ADG regardless of MR treatment (0.32 vs.

Table 3. Chemical analysis of milk replacers and calf starter.

\begin{tabular}{llll}
\hline Item & $\begin{array}{l}\text { Milk } \\
\text { replacer }\end{array}$ & $\begin{array}{l}\text { Egg milk } \\
\text { replacer }\end{array}$ & $\begin{array}{l}\text { Calf } \\
\text { starter }\end{array}$ \\
\hline DM, \% & 94.5 & 95.3 & 94.3 \\
CP (\% DM) & 21.9 & 22.7 & 23.9 \\
NDF (\% DM) & $\ldots$ & $\ldots$ & 25.9 \\
ADF (\% DM) & $\ldots$ & $\ldots$ & 9.1 \\
Fat (\% DM) & $\ldots$ & $\ldots$ & 3.5 \\
Fatty acids (\% DM) & 19.7 & 20.4 & $\ldots$ \\
Ca (\% DM) & 0.9 & 0.9 & 0.9 \\
P (\% DM) & 1.4 & 0.9 & 0.8 \\
\hline
\end{tabular}

$0.36 \mathrm{~kg}$, respectively). A significant postweaning colostrum $\times$ MR interaction $(P<0.05)$ was observed. Calves fed CS and EMR had a lower ADG than calves fed CS and AMR (0.56 vs. $0.74 \mathrm{~kg} / \mathrm{d}$, respectively). However, calves fed MC and EMR had similar ADG to calves fed $\mathrm{MC}$ and AMR (0.69 vs. $0.68 \mathrm{~kg} / \mathrm{d}$, respectively).

Calves fed MC were more efficient $(P<0.01)$ in the conversion of feed DM to BW gain preweaning than calves fed CS ( 0.44 vs. $0.34 \mathrm{~kg}$, respectively). Calves fed TI had higher $(P<0.05)$ feed efficiencies preweaning than calves not fed TI ( 0.42 vs. $0.36 \mathrm{~kg}$, respectively). Preweaning, calves fed EMR were less efficient $(P<$ $0.0001)$ than calves fed AMR ( 0.30 vs. $0.48 \mathrm{~kg}$, respectively). Overall, calves fed AMR were more efficient ( $P$ $<0.01)$ than calves fed EMR ( 0.47 vs. $0.40 \mathrm{~kg}$, respectively). Likewise, calves fed TI were more efficient ( $P$ $<0.05)$ than calves not fed TI $(0.46 \mathrm{vs} .0 .40 \mathrm{~kg}$, respectively).

A significant $(P<0.0001)$ preweaning $\mathrm{TI} \times \mathrm{MR}$ interaction was observed. Calves not fed TI and fed EMR were less efficient than calves not fed TI and fed AMR ( 0.34 vs. $0.38 \mathrm{~kg}$, respectively). However, calves fed TI and EMR were much less efficient than calves fed TI and AMR ( 0.26 vs. $0.58 \mathrm{~kg}$, respectively). Likewise, a significant $(P<0.001) \mathrm{TI} \times \mathrm{MR}$ interaction was observed overall. Calves not fed TI and fed EMR were more efficient than calves not fed TI and fed AMR ( 0.42 vs. 0.39 $\mathrm{kg}$, respectively). However, calves fed TI and EMR were less efficient than calves fed TI and AMR ( 0.38 vs. 0.54 $\mathrm{kg}$, respectively).

\section{DISCUSSION}

Absorption of IgG in calves fed MC and CS and resulting plasma IgG concentrations were consistent with 
Table 4. Least square means of DMI, starter DMI, weaning age, and BW of calves fed colostrum with (TI) or without trypsin inhibitor (No TI), colostrum supplement with or without trypsin inhibitor, followed by either all milk protein milk replacer (AMR) or 50\% egg-protein based milk replacer (EMR).

\begin{tabular}{|c|c|c|c|c|c|c|c|c|c|c|c|c|}
\hline \multirow{3}{*}{$\begin{array}{l}\text { Item and } \\
\text { period }\end{array}$} & \multicolumn{4}{|c|}{ Colostrum } & \multicolumn{4}{|c|}{ Colostrum supplement } & \multirow[b]{3}{*}{$\mathrm{SE}^{1}$} & \multirow{2}{*}{\multicolumn{3}{|c|}{ Contrasts $(P=)$}} \\
\hline & \multicolumn{2}{|c|}{ No TI } & \multicolumn{2}{|c|}{ TI } & \multicolumn{2}{|c|}{ No TI } & \multicolumn{2}{|c|}{ TI } & & & & \\
\hline & AMR & EMR & AMR & EMR & AMR & EMR & AMR & EMR & & $\mathrm{MC}$ vs. $\mathrm{CS}^{2}$ & No TI vs. $1 \mathrm{~g} \mathrm{TI}^{3}$ & AMR vs. $\mathrm{EMR}^{4}$ \\
\hline & & & & & $(\mathrm{kg} / \mathrm{d})$ & & & & & & & \\
\hline \multicolumn{13}{|l|}{ DMI } \\
\hline Preweaning & 0.79 & 0.89 & 0.83 & 0.86 & 0.93 & 0.88 & 0.83 & 0.78 & 0.05 & $\mathrm{NS}^{5}$ & NS & NS \\
\hline Postweaning & 1.36 & 1.76 & 1.64 & 1.61 & 1.73 & 1.30 & 1.64 & 1.00 & 0.19 & NS & NS & NS \\
\hline Preweaning & 0.26 & 0.33 & 0.30 & 0.29 & 0.40 & 0.32 & 0.29 & 0.23 & 0.05 & NS & NS & NS \\
\hline Postweaning & 1.32 & 1.66 & 1.57 & 1.57 & 1.69 & 1.27 & 1.57 & 1.04 & 0.20 & NS & NS & NS \\
\hline Overall & 0.67 & 0.90 & 0.84 & 0.82 & 0.87 & 0.70 & 0.80 & 0.56 & 0.10 & NS & NS & NS \\
\hline $\begin{array}{l}\text { Weaning age, } d \\
\text { BW }\end{array}$ & 36 & 34 & 34 & 33 & 35 & 34 & 34 & 34 & 1.05 & NS & NS & NS \\
\hline Preweaning & 49.6 & 50.8 & 52.8 & 51.5 & 52.9 & 50.0 & 53.8 & 46.3 & 2.3 & NS & NS & NS \\
\hline Postweaning & 61.1 & 68.4 & 70.1 & 65.4 & 68.7 & 63.0 & 70.3 & 57.8 & 4.3 & NS & NS & NS \\
\hline
\end{tabular}

${ }^{1}$ Mean standard error.

${ }^{2}$ Maternal colostrum vs. colostrum supplement.

${ }^{3}$ No trypsin inhibitor vs. $1 \mathrm{~g}$ of trypsin inhibitor.

${ }^{4}$ All milk protein milk replacer vs. 50\% egg-protein milk replacer.

${ }^{5}$ Not significant $(P \leq 0.10)$.

other reports. The proportion of calves fed $\mathrm{MC}$ with the failure of passive transfer was $4.2 \%$. Conversely, all calves fed CS had failure of passive transfer. Passive transfer is defined as a calf having a serum IgG concentration of $10 \mathrm{~g} / \mathrm{L}$ by $48 \mathrm{~h}$ after birth (Bovine Alliance on Management and Nutrition, 1995). Mean serum IgG concentration of calves fed CS at $24 \mathrm{~h}$ of age was $4.5 \mathrm{~g} /$ $\mathrm{L}$ and was lower than in calves in which this product completely replaced MC (Quigley et al., 1998b, 2000; Arthington et al., 2000; Quigley, 2002). However, AEA was similar among treatments, suggesting that feeding more CS might have resulted in adequate serum IgG.

Calves fed the CS had increased postweaning fecal scores and increased overall fecal scores than calves fed MC. Other researchers found no differences in fecal scores between calves fed CS and MC (Nousiainen et al., 1994; Seymour et al., 1995; Mee et al., 1996). Likewise, days medicated were increased for calves fed CS. This was likely due to reduced IgG intake in the calves fed CS, which are inconsistent with the results of Scott et al. (1999) and Kellogg et al. (2000), who observed no differences in disease incidence or fecal consistency in calves fed MR containing spray-dried egg.

There were no effects of treatment on feed intake in our experiment (Table 4). Kellogg et al. (2000) found no differences in DMI between calves fed an MR containing 30\% spray-dried whole egg and calves fed an AMR, whereas Scott et al. (1999), who fed an EMR similar to the one fed in our study, and Quigley (2002), who fed an MR containing either 10 or $20 \%$ spray-dried whole egg, observed reductions in DMI compared to AMR. Hill et al. (2001) observed a reduction in starter intake when egg provided $30 \%$ of the CP in their MR. Moreover, these same researchers observed no differences in performance in calves fed an MR containing $15 \%$ CP from eggs. However, the egg used in these experiments was from a different source, suggesting that source of egg affects performance. Catherman (2002) observed reduced starter intake when calves were fed an EMR similar to the one used in the present study or one containing $9 \%$ albumin. In our experiment, calves consuming MC and EMR performed better in regards to DMI and starter intake as compared with calves consuming MC and AMR.

Soybean TI addition had no effect on DMI. This concurs with the previous work of Quigley et al. (1995b), which showed no effect of feeding TI on DMI. The addition of TI to the CS had no effect on BW or ADG (Tables 4 and 5). Feeding TI reduced ADG in calves fed EMR. There is no explanation for this interaction.

Calves fed EMR had a 32\% lower ADG than calves fed AMR preweaning (Table 5). Quigley (2002) also observed a $32 \%$ reduction in ADG in calves fed EMR, possibly, avidin from the egg-bound biotin. Calves in the present study and in that of Kellogg et al. (2000) and Catherman (2002) were fed starter. Calves in the experiments of Scott et al. (1999) and Quigley (2002) were not fed starter until later. Rumen microorgan- 
Table 5. Least square means of average daily gain and feed efficiency of calves fed colostrum with or without trypsin inhibitor, colostrum supplement with (TI) or without trypsin inhibitor (No TI), followed by either all milk protein milk placer (AMR) or 50\% egg-protein based milk replacer (EMR).

\begin{tabular}{|c|c|c|c|c|c|c|c|c|c|c|c|c|}
\hline \multirow{3}{*}{$\begin{array}{l}\text { Item and } \\
\text { period }\end{array}$} & \multicolumn{4}{|c|}{ Colostrum } & \multicolumn{4}{|c|}{ Colostrum supplement } & \multirow[b]{3}{*}{$\mathrm{SE}^{1}$} & \multirow{2}{*}{\multicolumn{3}{|c|}{ Contrasts $(P=)$}} \\
\hline & \multicolumn{2}{|c|}{ No TI } & \multicolumn{2}{|c|}{ TI } & \multicolumn{2}{|c|}{ No TI } & \multicolumn{2}{|c|}{ TI } & & & & \\
\hline & AMR & EMR & AMR & EMR & AMR & EMR & AMR & EMR & & $\mathrm{MC}$ vs. $\mathrm{CS}^{2}$ & No TI vs. $1 \mathrm{~g} \mathrm{\textrm {TI } ^ { 3 }}$ & AMR vs. $\mathrm{EMR}^{4}$ \\
\hline & & & & - $(\mathrm{kg}$ & /d) & & & & & & & \\
\hline \multicolumn{13}{|c|}{ Average daily gain } \\
\hline Preweaning & 0.39 & 0.34 & 0.43 & 0.28 & 0.34 & 0.31 & 0.46 & 0.17 & 0.06 & $\mathrm{NS}^{5}$ & NS & 0.003 \\
\hline Postweaning & 0.59 & 0.94 & 0.77 & 0.73 & 0.75 & 0.59 & 0.73 & 0.54 & 0.10 & NS & NS & NS \\
\hline \multicolumn{13}{|l|}{ Feed efficiency } \\
\hline Preweaning & 0.47 & 0.36 & 0.59 & 0.32 & 0.28 & 0.31 & 0.57 & 0.20 & 0.05 & 0.01 & 0.05 & 0.0001 \\
\hline Postweaning & 0.40 & 0.58 & 0.55 & 0.45 & 0.50 & 0.45 & 0.45 & 0.60 & 0.03 & $\mathrm{NS}^{5}$ & NS & 0.06 \\
\hline Overall & 0.41 & 0.46 & 0.57 & 0.39 & 0.37 & 0.37 & 0.51 & 0.38 & 0.04 & 0.10 & 0.02 & 0.01 \\
\hline
\end{tabular}

${ }^{1}$ Mean standard error.

${ }^{2}$ Maternal colostrum vs. colostrum supplement.

${ }^{3}$ No trypsin inhibitor vs. $1 \mathrm{~g}$ of trypsin inhibitor.

${ }^{4}$ All milk protein milk replacer vs. $50 \%$ egg-protein milk replacer.

${ }^{5}$ Not significant $(P \leq 0.10)$.

isms, which multiply in the rumen of calves that are fed solid feed, synthesize biotin and may have produced enough to compensate for any biotin binding by avidin in these calves. These results may be due to an antinutritional factor in the EMR. However, the study of Quigley (2002) and our experiment used EMR that had supplemental biotin added, which suggests that another antinutritional factor is present or a nutrient was missing. Quigley (2002) stated that there is a lack of information on the digestibility of egg lipid, which is primarily located in the yolk. Catherman (2002) fed an EMR, similar to our study, along with diets containing 9\% egg albumin and 6\% egg yolk. He observed no differences in gain between calves fed an AMR and calves fed a milk replacer containing egg yolk, suggesting that the antinutritional factor is not contained within the egg yolk but must be found in the egg albumin fraction. A postweaning interaction for colostrum $\times$ MR suggests that calves fed MC and EMR experienced compensatory gain.

Feeding MC compared with CS improved feed efficiency preweaning. This result was inconsistent with the results of Seymour et al. (1995), who observed that calves fed a whey protein concentrate CS had as high a feed efficiency as calves fed MC. Nevertheless, it is possible that MC-fed calves had better feed efficiency because they suffered fewer medical problems compared with calves fed the CS. This lack of stress may have allowed more nutrients to be directed for growth. While not significantly different, calves fed MC had a greater ADG $(40 \mathrm{~g} / \mathrm{d})$ and a lower DMI $(15 \mathrm{~g} / \mathrm{d})$ than calves fed CS during the preweaning phase. The im- provement in feed efficiency from feeding TI (Table 5) agrees with Quigley et al. (1995b). Reasons for this result are unknown.

Calves fed the EMR had lower feed efficiency due to poor growth rates preweaning (Table 5). Feed efficiency was 37.5\% lower for calves fed EMR. The preweaning data agree with that of Quigley (2002) and Scott et al. (1999), who observed a $38 \%$ reduction in feed efficiency in calves fed an EMR. Based on DMI, starter intake, BW, and ADG calves fed CS and EMR responded poorly compared with calves fed CS and AMR. However, when MC was fed, calves fed EMR responded at equivalent or better than calves fed MC and AMR. Milk replacer containing spray-dried whole egg when fed to calves receiving good quality colostrum performs like calves fed conventional AMR.

Calves fed the EMR in the study conducted by Quigley (2002) tended to have lower initial IgG than control calves $(7.7 \mathrm{~g} / \mathrm{L}$ vs. $10.4 \mathrm{~g} / \mathrm{L}$, respectively). Based on the colostrum $\times$ MR interaction in our study, the results of the experiment conducted by Quigley (2002) may have been different if the IgG concentration in the calves fed EMR was higher (>10 g/L).

Calves fed TI and EMR reacted poorly in regards to BW, ADG, and feed efficiency compared with calves fed TI and AMR. However, when EMR was fed and TI was not fed, calves reacted in a similar fashion to calves not fed TI and AMR. We do not have an explanation for these results.

\section{CONCLUSION}

Calves fed CS had lower serum IgG concentration compared with calves fed MC but had similar AEA. The 
addition of soybean TI was not beneficial to either MC or CS, as determined by serum IgG concentration over the first $24 \mathrm{~h}$ of life. Results also indicate that calves fed EMR performed as well as calves fed AMR if they are fed MC. When EMR is fed to calves previously fed CS, these calves do not perform as well as calves fed AMR and previously fed CS. Therefore, EMR can be fed to calves if $\mathrm{MC}$ is fed to these calves during the first $24 \mathrm{~h}$ of life.

\section{ACKNOWLEDGMENTS}

The authors thank the staff of the University of New Hampshire Dairy Teaching and Research Center for help in conducting the experiment. Appreciation is extended to APC, Inc., for financial support, milk replacers, and IgG analysis and to Celeste Dietterle for typing the manuscript.

\section{REFERENCES}

Arthington, J. D., M. B. Cattell, and J. D. Quigley, III. 2000. Effect of dietary IgG source (colostrum, serum or milk-derived supplement) on the efficiency of Ig absorption in newborn Holstein calves. J. Dairy Sci. 83:1463-1467.

Association of Official Analytical Chemists. 1979. Protein (crude) in animal feed semi-automated method. 976.06. J. AOAC 62:290.

Association of Official Analytical Chemists. 1995. Official Methods of Analysis. 16th ed. AOAC, Washington, DC.

Bovine Alliance on Management and Nutrition. 1995. A guide to colostrum and colostrum management for dairy calves. AFIA, Arlington, VA.

Catherman, D. R. 2002. Evaluation of dried whole egg and egg components in calf milk replacers. J. Dairy Sci. 85(Suppl. 1):307. (Abstr.)

Davis, C. L., and J. K. Drackley. 1998. The development, nutrition and management of the young calf. Iowa State University Press, Ames.

Etzel, L. R., R. E. Strohbehn, and J. K. McVicker. 1997. Development of an automated turbidimetric immunoassay for quantification of bovine serum immunoglobulin G. J. Vet. Res. 58:1201-1205.
Goering, H. K., and P. J. Van Soest. 1970. Forage fiber analysis (apparatus, reagents, procedures and some applications). Agric. Handbook No. 379. ARS-USDA, Washington, DC.

Heinrichs, A. J., S. J. Wells, and W. C. Losinger. 1995. A study of the use of milk replacers for dairy calves in the United States. J. Dairy Sci. 78:2831-2837.

Hill, T. M., J. M. Aldrich, A. J. Proeschel, and R. L. Scholotterbeck. 2001. Feeding neonatal calves milk replacers (MR) containing egg proteins. J. Dairy Sci. 84(Suppl. 1):265. (Abstr.)

Kellogg, D. W., K. S. Anschutz, Z. B. Johnson, K. E. Lesmeister, and A. K. M. A. Haque. 2000. Growth of calves fed milk replacer containing egg product. J. Dairy Sci. 83(Suppl. 1):251. (Abstr.)

Mee, J. F., K. J. Farrell, P. Ratsma, and R. Mehra. 1996. Effect of a whey protein concentrate used as a colostrum substitute or supplement on calf immunity, weight gain, and health. J. Dairy Sci. 79:886-894.

Nousiainen, J. H., E. Kormonen, S. Syvaoya, H. Savolainen, H. Saloniemi, and H. Jolonen. The effect of colostral immunoglobulin supplement on the passive immunity, growth and health of neonatal calves. Agric. Sci. Finland 3:421-427.

Quigley, J. D., III. 2002. Effect of spray-dried whole egg and biotin in calf milk replacer. J. Dairy Sci. 85:198-203.

Quigley, J. D., III, J. J. Drewry, and K. R. Martin. 1998a. Estimation of plasma volume in Holstein and Jersey calves. J. Dairy Sci. 81:1308-1312.

Quigley, J. D., III, D. L. Fike, M. N. Egerton, J. J. Drewry, and J. D. Arthington. 1998b. Effects of a colostrum replacement product derived from serum on immunoglobulin $\mathrm{G}$ absorption by calves. J. Dairy Sci. 81:1936-1939.

Quigley, J. D., III, K. R. Martin, and H. H. Dowlen. 1995a. Concentrations of trypsin inhibitor and immunoglobulins in colostrum of Jersey cows. J. Dairy Sci. 78:1573-1577.

Quigley, J. D., III, K. R. Martin, H. H. Dowlen, and K. C. Lamer. 1995b. Addition of soybean trypsin inhibitor to bovine colostrum: Effects on serum immunoglobulin concentrations in Jersey calves. J. Dairy Sci. 78:886-892.

Sandholm, M., and T. Hokanen-Byzalski. 1979. Colostral trypsininhibitor capacity in different animal species. Acta Vet. Scand. 20:469-476.

SAS/STAT User's Guide. 2000. Version 8 Edition 2000. SAS Inst., Inc., Cary, NC.

Seymour, W. M., J. E. Nocek, and J. Siciliano-Jones. 1995. Effects of a colostrum substitute and of dietary brewer's yeast on the health and performance of dairy calves. J. Dairy Sci. 78:412-420.

Scott, T. A., T. Tompkins, D. Vermeire, and N. K. Keith. 1999. Evaluation of alternate protein milk replacers on growth and health of Holstein heifer calves. J. Dairy Sci. 82(Suppl. 1):46-47. (Abstr.) 